\title{
Natural infection by Microsporum canis in a capuchin monkey
}

\author{
Stéphanie Machado Mota ${ }^{1}$ Adriano Fernandes Ferreira ${ }^{2}$ Thiago Lopes Nery ${ }^{3}$ \\ Roberto Citelli de Farias $^{3}$ Amanda Figueiredo Mangueira ${ }^{2}$ Felisbina Luísa Queiroga ${ }^{1,4}$ \\ ${ }^{1}$ Departamento de Ciências Veterinárias, Universidade de Trás-os-Montes e Alto Douro, Vila Real, Portugal. \\ ${ }^{2}$ Centro de Saúde e Tecnologia Rural, Universidade Federal de Campina Grande (UFCG), Campina Grande, PB, Brasil. \\ ${ }^{3}$ Parque Zoobotânico Arruda da Câmara, João Pessoa, PB, Brasil. \\ ${ }^{4}$ Departamento de Ciências Veterinárias, Centro de Investigação e Tecnologias Agroambientais e Biológicas (CITAB), Universidade de Trás-os-Montes e \\ Alto Douro, 5001-801, Vila Real, Portugal. E-mail: fqueirog@utad.pt. Corresponding author.
}

ABSTRACT: This paper described a case of a capuchin monkey (Sapajus libidinosus) with non-pruritic skin lesions. During the physical examination, multifocal areas of alopecia with crusts, erythema and scaling compatible with dermatophytosis were reported on the right fore and hind limbs and on tail. Fungal culture findings revealed a diagnosis of dermatophytosis due to Microsporum canis. The animal was successfully treated with itraconazole. This is the first report of a dermatophytosis case in S. libidinosus and the first description of an effective treatment in this species.

Key words: dermatology, ringworm, tinea, nonhuman primates, Sapajus libidinosus.

Infeção natural por Microsporum canis em macaco capuchinho

RESUMO: O presente trabalho relata o caso de um macaco capuchinho (Sapajus libidinosus) com lesões de pele não-pruriginosas. Durante o exame físico foram encontradas lesões multifocais com crostas, eritema e descamação compatíveis com dermatofitose, nos membros anterior e posterior direitos, bem como na cauda. O animal não tinha outras alterações. O diagnóstico de dermatofitose por Microsporum canis foi realizado através de cultura fúngica das lesões. O animal foi tratado com sucesso com itraconazol. Este é o primeiro relato de um caso de dermatofitose em S. libidinosus e a primeira descrição de um tratamento eficaz para esta espécie. Palavras-chave: dermatologia, dermatofitose, tinha, primatas não-humanos, Sapajus libidinosus.

Dermatophytosis, also called ringworm or tinea, is a superficial infection of hair, skin and nails (MIGAKI, 1986; PIER et al., 1994; BIELITZKI, 1998; CHERMETTE et al., 2008). It may involve one or more fungal species of keratinophilic genera Microsporum, Trichophyton and Epidermophyton (MIGAKI, 1986; MECKLENBURG et al., 2011). The great importance of ringworm can be explained by the consequences of infections amongst animal communities, cost of treatment, difficulty of control measures, and the issue of public health- especially given that the majority of dermatophytes isolated from animals are zoonotic (PIER, et al., 1994; CHERMETTE et al., 2008).

In nonhuman primates (NHP) Microsporum and Trichophyton are usually the genera responsible for causing this pathology (BAGNALL \& GRUNBERG, 1972; BIELITZKI, 1998; GIBSON, 1998). Microsporum spp., which is a common cause of ringworm in dogs and cats, has also been isolated from NHP (old and new world monkeys). As for old world monkeys, this pathology has only been described in a reduced number of cases (KLOKKE \& DE VRIES, 1963; SEELIGER et al., 1963; AVNIMAGEN, et al.,2008). Regarding new world monkeys, most of the references date back several decades, with emphasis given to a case in Philadelphia (USA) of a capuchin monkey that was imported from Nicaragua (SCULLY \& KLIGMAN, 1951; KAPLAN et al., 1958). Furthermore, there are no reports in literature referring to any infections by Microsporum canis in Sapajus libidinosus monkeys.

S. libidinosus is a new world monkey that belongs to the family Cebidae, and is found in the North East of Brazil. (FRAGASZY, 2004; RYLANDS, KIERULFF, 2008; ALFARO, 2012). Primates belonging to this genus are medium-sized animals with a semi-prehensile tail, and with arboreal and diurnal habits (FRAGASZY, 2004; FEDULLO, 2013). 
This report described one case of dermatophytosis caused by M. canis in S. libidinosus, which was successfully treated in the Zoobotanic Park Arruda Câmara in João Pessoa, Paraíba, Brazil.

A male $S$. libidinosus, aging five to six months, was admitted to the Zoobotanic Park Arruda Câmara in João Pessoa, Paraíba, Brazil. The animal was kept in illegal captivity and had been rescued by IBAMA (Brazilian Institute of Environment and Renewable Natural Resources). Physical examination conducted by the Zoo's veterinary staff showed the presence of multifocal areas of alopecia with crusts, erythema and scaling compatible with dermatophytosis. These lesions were present in the right fore and hind limbs and in the tail. The animal had no other changes.

To establish a definitive diagnosis, skin scrapings and fur were collected from three distinct lesions and sent for microbiological analysis. Before sampling, lesions were thoroughly cleaned with alcohol to remove debris and to limit the growth of contaminants. Moreover, lesions were shaved deeply enough to cause some bleeding and to verify the presence of ectoparasites. Samples were obtained from the margin of lesions. Hair and scab samples were cultured in Petri dishes containing Sabouraud Dextrose Agar (SDA) with yeast extract, chloramphenicol and cycloheximide. Petri dishes were incubated aerobically at $25^{\circ} \mathrm{C}$ and examined daily for five weeks. Thick-walled, fusoid-apiculate, rough-walled macroconidia and a lemon-yellow colony pigmentation were seen. Fungal culture was positive for $M$. canis in all the samples analyzed.

The animal was treated with itraconazole (Cepav Pharma, São Paulo, Brazil), $10 \mathrm{mg} \mathrm{kg}^{-1}$ day $^{-1}$ PO (CARPENTER, 2012) mixed with smashed bananas and papaya for 30 days. Clinical improvement could be seen after just two weeks of treatment, with a decrease in the number of lesions and size of alopecic areas. After 20 days of treatment, significant improvements had taken place, and any clinical signs of the lesions, other than incomplete growth of hair, were completely absent. The protocol was continued for 10 more days, in order to complete the full 30 days of treatment. The animal was monitored for yet another 30 days after the last administration of itraconazole - a period during which its hair clearly grew.

Case reports on the isolation of $M$. canis in NHP dermatology, especially in new world primates, are very rare in literature (FOWLER \& CUBAS, 2001). In fact, this is the first report of $M$. canis affecting $S$. libidinosus. The literature available does not provide an organized evidence-based approach to the NHP dermatological cases (BERNSTEIN \& DIDIER, 2009).
However, one should be aware that they occur and can have zoonotic significance (MIGAKI, 1986; FOWLER \& CUBAS, 2001; RYLANDS, 2001; SCHMIDT, 2001; BERNSTEIN \& DIDIER, 2009).

Animals of any age, gender and species are susceptible to infection, but the condition is most common in young, sick, elderly and frail individuals (CHERMETTE et al., 2008). It is also possible for the animal to incubate these pathogens and develop them in favorable conditions, such as stress experienced in captivity (ROBERTS \& ANDREWS, 2008). In this case, we present a young animal that had been captured by IBAMA and probably was in a very stressful situation.

Skin lesions identified in this case report are compatible with those described by several authors in other primate species in cases of dermatophytosis, although the diagnosis has only been confirmed from the isolation of pure colonies of M. canis in SDA. According to the literature, the main clinical features are regular alopecia with erythema and scaling, usually non-pruritic; although, various degrees of infection may modify this typical aspect. Lesions may be localized, generalized or multifocal (MIGAKI, 1986; CHERMETTE, 2008; BERNSTEIN \& DIDIER, 2009).

An effective treatment is important in order to limit the spread of arthroconidia to other animals and people, as well as to minimize environmental contamination (CHERMETTE et al., 2008). This case report demonstrated that treatment with itraconazole was effective, with the animal showing no further clinical signs of infection and apparently without any side effects. The authors chose this therapy, previously used in primates (AVNI-MAGEN, 2008), because it was possible to administer it orally and only once a day, as well as because of its rarely reported side effects (GRANT \& CLISSOLD, 1989). At the beginning of treatment; however, we had some difficulty in administering the medication, as it is hard to hide medication and deceive such an intelligent species. Therefore, the person in charge of the administration was always the same and was someone whom the monkey knew and liked.

In conclusion, the present report contributed to the published literature on NHP dermatology as, dermatophytosis is a result of $M$. canis infection has not been previously reported in a S. libidinosus. Moreover, it was also demonstrated that an oral treatment with itraconazole is effective in allowing the animal to completely recover.

\section{BIOETHICS AND BIOSSECURITY COMMIITTE APPROVAL}

We, authors of the article entitled "Naturally infection of Microsporum cannis in a capuchin monkey" declared, for all due 
purposes, that the project which gave rise to the present data has not been submitted for evaluation to the Ethics Committee of the Universidade de Trás-os-Montes e Alto Douro, Vila Real, Portugal, but are aware of the content of the Brazilian resolutions of the National Council for Control of Animal Experimentation-CONCE $<$ http://www.mct.gov.br/index.php/content/view/310553.html $>$ if it involves animals. Thus, authors assume full responsibility for the presented data and are available for possible questions, should they be required by the competent authorities.

\section{REFERENCES}

ALFARO, J.W. et al. How different are robust and gracile capuchin monkeys? An argument for the use of Sapajus and Cebus. American Journal of Primatology, v.74, n.4, p.273-286, 2012 Available from: <http://onlinelibrary.wiley.com/doi/10.1002/ ajp.22007/pdf>. Accessed: Nov. 10, 2014. doi: 10.1002/ajp.22007.

AVNI-MAGEN, N. et al. Use of a sustained release preparation of clotrimazole to treat dermatophytosis in a siamang(Hylobates syndactylus). Journal of Zoo and Wildlife Medicine, v.39, n.1, p.115-117, 2008. Available from: <http://www.bioone.org/doi/abs/10.1638/2007-0018.1>. Accessed: nov. 10, 2014. doi: 10.1638/2007-0018.1.

BAGNALL, B.G.; GRUNBERG W. Generalized Trhichophyton mentagrophytes ringworm in capuchin monkeys (Cebus nigrivitatus). British Journal of Dermatology, v.87, n.6, p.565-570, 1972. Available from: <http://onlinelibrary.wiley.com/doi/10.1111/j.1365-2133.1972. tb07446.x/pdf >. Accessed: Nov. 10, 2014. doi: 10.1111/j.13652133.1972.tb07446.x

BERNSTEIN, J.A.; DIDIER, P.J. Nonhuman primate dermatology: a literature review. Veterinary Dermatology, v.20, n.3, p.145-156, 2009. Available from: $<$ http://europepmc.org/articles/pmc4416230>. Accessed: Nov. 10, 2014. doi: 10.1111/j.1365-3164.2009.00742.x.

BIELITZKI, J.T. Integumentary system. In: BENNETT, B.T. et al. Nonhuman primates in biomedical research: disease. San Diego: Academic, 1998. p.363-375.

CARPENTER, J.W. Exotic animal formulary. 4.ed. Saint Louis: Elsevier Saunders, 2012. 619p.

CHERMETTE, R. et al. Dermatophytoses in animals. Mycopathologia, v.166, n.5-6, p.385-405, 2008. Available from: <http://link.springer. com/article/10.1007/s11046-008-9102-7\#/page-1>. Accessed: Nov. 10 2014. doi: 10.1007/s11046-008-9102-7.

FEDULLO, J.D.L. et al. Skin mycoflora of Cebus primates kept in captivity and semicaptivity. Journal of Medical Primatology, v.42, n.6), p.293-299, 2013. Available from: <http://onlinelibrary.wiley. com/doi/10.1111/jmp.12056/pdf>. Accessed: Nov. 10, 2014. doi: $10.1111 /$ jmp. 12056

FOWLER, M.E.; CUBAS, Z.S. Biology, medicine, and surgery of South America wild animals. USA: Iowa State University, 2001. p.267-272

FRAGASZY, D.M. The complete capuchin: the biology of the genus Cebus. Cambridge: University, 2004. p.13-28.
GIBSON, S.V. Bacterial and mycotic diseases. In: BENNETT, B.T. et al. Nonhuman primates in biomedical research: diseases. San Diego: Academic, 1998. p.59-110.

GRANT, S.M; CLISSOLD, S.P. Itraconazole. Drugs, v.37, n.3, p.310-344, 1989. Available from: < http://link.springer.com/ article/10.2165/00003495-198937030-00003>. Accessed: Nov. 10, 2014. doi: 10.2165/00003495-198937030-00003.

KAPLAN, W. et al. Recent developments in animal ringworm and their public health implications. Annals of the New York Academy of Sciences, v.70, n.3, p.636-649, 1958. Available from: <http:// onlinelibrary.wiley.com/doi/10.1111/j.1749-6632.1958.tb35419.x/pdf $>$. Accessed: Nov. 10, 2014. doi: 10.1111/j.1749-6632.1958.tb35419.x.

KLOKKE, A.H.; DE VRIES, G.A. Tinea capitis in chimpanzees caused by Microsporum canis bondin 1902 resembling M. obesum Conant 1937. Medical Mycology, v.2, n.4, p.268-270, 1963. Available from: $<$ http://sabouraudia.oxfordjournals.org/content/2/4/268.full.pdf + html $>$. Accessed: Nov. 10, 2014. doi: 10.1080/00362176385190421.

MIGAKI, G. Mycotic infections in nonhuman primates. In MIGAKI, G. Primates. Springer: New York, 1986. p.557-570.

PIER, A.C. et al. Animal ringworm - its aetiology, public health significance and control. Journal of Medical and Veterinary Mycology, v.32, Suppl 1, p.133-150, 1994. Available from: <http://www. tandfonline.com/doi/abs/10.1080/02681219480000791? journalCode $=\mathrm{i}$ mmy19>. Accessed: Nov. 10, 2014. doi: 10.1080/02681219480000791.

ROBERTS, J.A.; ANDREWS, K. Nonhuman primate quarantine: its evolution and practice. Institute for Laboratory Animal Research, v.49, n.2, p.145-156, 2008. Available from: <http://ilarjournal. oxfordjournals.org/content/49/2/145.full>. Accessed: Nov. 10, 2014. doi: 10.1093/ilar.49.2.145.

RYLANDS, A.B. et al. Order primates. In: FOWLER, M.E.; CUBAS, Z.S. Biology, medicine, and surgery of South American wild animals. Ames: Iowa University, 2001. p.256-278.

RYLANDS, A.B.; KIERULFF, M.C.M. Cebus libidinosus. 2008 Online. Available from: $<$ http://www.iucnredlist.org $>$. Accessed June 15, 2014.

SCHMIDT, R.E. Veterinary Clinics oh North America: Exotic Animals: Dermatology. v.4, n.2, p.573-581, 2001.

SCULLY, J.P.; KLIGMAN, A.M. Coincident infection of a human and an anthropoid with Microsporum audouini: report of a case. AMA Archives of Dermatology and Syphilology, v.64, n.4, p.495-498, 1951. Available from: <http://archderm.jamanetwork.com/article. aspx? articleid $=522977>$. Accessed: Nov. 10, 2014. doi: 10.1001/ archderm.1951.01570100112017.

SEELIGER, H.P.R. et al. Über eine Microsporum -Enzootie bei Kappen-Gibbons (Hylobates lar) verursacht durch eine Variante von Microsporum canis [About a Microsporum enzootic in white-handed gibbons (Hylobates lar) caused by a variant of Microsporum canis]. Mykosen, v.6, n.3, p.61-68, 1963. Available from: <http://onlinelibrary. wiley.com/doi/10.1111/j.1439-0507.1963.tb02328.x/pdf>. Accessed: Nov. 10, 2014. doi: 10.1111/j.1439-0507.1963.tb02328.x. 